\title{
Assessment of the impact of local energy policies in reducing greenhouse gas emissions
}

\author{
A. Arteconi, C. M. Bartolini, C. Brandoni \& F. Polonara \\ Department of Energy, Polytechnic Marche, Italy
}

\begin{abstract}
The present work investigates the potential energy savings coming from a careful and detailed local energy policy. The paper analyzes and assesses from technical, economic and environmental viewpoints different initiatives in the energy sector aimed at increasing energy efficiency in end-uses and reducing overall carbon emissions. The results are based on energy planning for five Italian urban areas sized at about fifty thousand inhabitants. The analysis has been developed with the aim of reaching generally applicable criteria suitable for evaluating the local energy policy contribution to the greenhouse gas (GHG) emissions reduction. Several initiatives for the private and public sectors have been considered, such as: (i) the introduction of combined heat and power generation based on useful thermal demand, suitable for the industry and service sectors (swimming pools, large distribution organizations); (ii) generation of electricity from renewables (solar energy, biomass); (iii) thermal insulation of private and public buildings, such as schools; (iv) introduction of micro-combined heat and power generation in the residential sector. For each solution the primary energy reduction and the consequent reduction in GHG emissions have been evaluated and a feasibility analysis has been developed in order to assess the profitability of the investment. Great attention has been paid to the public sector, which has an important role in providing leadership and driving changes in other sectors; furthermore, a rational use of energy combined with the exploitation of country-based incentives is able to reduce the public administrative expenditure. The results show that local energy policy can give an important contribution to gas emission reduction targets, and underline the fundamental role of public sector initiatives.
\end{abstract}

Keywords: municipal planning, energy policy, renewable, energy savings, micro-CHP. 


\section{Introduction}

Copenhagen United Nations Climate Change Conference ended in December 2009 with a political agreement that recognized climate change as one of the greatest challenges of our time. It was decided to cap temperature rise under two degrees, to reduce emissions and to raise finance for actions aimed at combating climate change [1]. The Copenhagen Accord can be considered as the first step that involves most countries and gives basis to an international operative program, but it was not legally binding for the parties. In order to activate GHG emission reduction initiatives, most countries understand the importance of strategic energy planning not only on a national scale, but also on regional and local levels [2]. Even in the US [3], which first rejected mandatory targets for curbing emissions under the Kyoto Protocol, lots of actions have been undertaken in the energy sector at the local level, in order to fill the federal leadership vacuum. In recent years many urban areas have developed municipal energy planning, adopting an environmental sustainability policy to improve living conditions and environments [4]. Several discussion networks were born in Europe and abroad with the aim of sharing energy savings 'bottom-up' initiatives and assessing the potential of local energy policy instruments. Furthermore, several initiatives were undertaken, as Local Agenda 21, to assist local authorities in Climate Protection Campaigns. The need to catch the economic opportunities of investment in energy efficiency and renewables, in order to reduce the administrative expenditure, is another important factor emphasizing the importance of local energy policy. As a matter of fact, by encouraging local energy policy it is possible to create jobs and generate revenue for the local economy. In Italy the importance of municipal energy planning was first outlined with Italian national law no.10/91, which defined the basis for national Energy Planning development and was focused on developing local energy programs for the rational exploitation of renewable resources for urban areas with more than 50 thousands inhabitants. In recent years funds have been allocated to develop municipal energy programs in order to increase energy efficiency in end-uses, and adopt a rational exploitation of renewables. In the case under study the Regional Government provided a loan to municipalities characterized by having about fifty thousand inhabitants, in order to develop environmental and energy programs with the aim of integrating energy into the local policy.

\section{Methodology}

The results are based on five municipal energy and environmental plans of urban areas located in central Italy with about fifty thousand inhabitants. Table 1 shows the number of citizens registered in 2008. The analysis has been developed in order to reach generally applicable criteria suitable to evaluate the local energy policy contribution to the greenhouse gas (GHG) emissions reduction. Each energy municipal plan is made up of three phases: (i) an investigative phase that analyzes the local energy supply and demand in order to point out criticalities in 
energy production and end-users, (ii) an analysis phase that studies the actions to improve a rational use of energy and renewables, (iii) an executive phase where the potential GHG emission reduction is assessed. In all of the analyses of energy supply and demand, the public sector has been considered independently.

The public sector actually has an important role in providing leadership and driving changes in other sectors. In the analysis phase each initiative has been analyzed from both energy and economic viewpoints. When possible, a standard action and the simple pay back method has been defined, eqn. (1), and has been used to assess the economic profitability of the investment, based on the calculation of the initial investment, Ex, and on annual cash flow, F, generated by the energy-saving solution.

$$
P B P=\frac{E x}{F}
$$

In the executive phase, firstly, the potential reduction in primary energy derived from the energy saving actions and its real feasibility on the basis of factors derived from literature and the author's experience has been assessed. Secondly, the GHG emission reduction has been calculated using emission factors. Furthermore, in order to generalize results, some generalized factors, suitable for estimating the contribution of the local 'bottom-up' initiative, have been found.

\section{Investigative phase}

Figures 2 and 3 show the percentage sector shares in total electric and thermal consumption for the five urban areas analyzed.

Table 1: $\quad$ Number of citizens in the urban areas under study.

\begin{tabular}{|l|c|c|c|c|c|}
\hline urban areas & 1 & 2 & 3 & 4 & 5 \\
\hline inhabitants & 44,207 & 93,488 & 41,056 & 51,503 & 63,734 \\
\hline
\end{tabular}

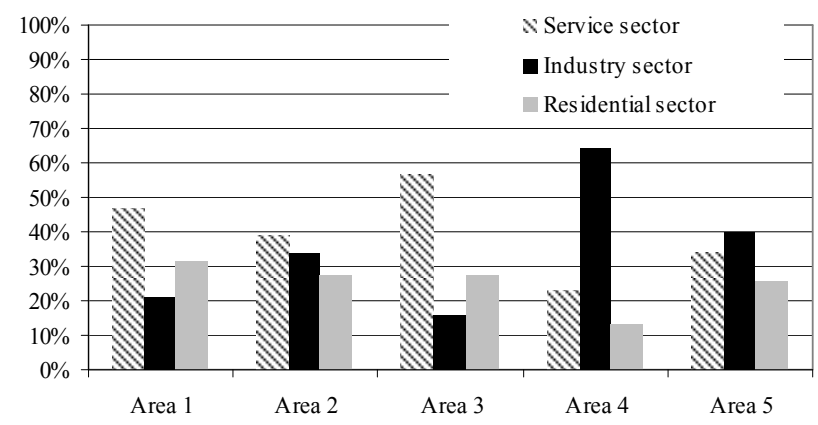

Figure 1: Electric consumption. 
Except for the area No. 4, which is characterized by a high incidence of the industry sector, due the presence of energy intensive industries, such as paper industry, and to a smaller extent the area No. 5, the service sector is the most critical one in the total electric consumption.

The energy consumption of the service sector comprises the energy used in private and public buildings. Due to the tertiarization of the economy the service sector incidence in energy consumption is becoming more and more important. As far as the thermal demand is concerned, the most critical activity sector is the residential one.

The number of dwellings by year of construction has been analyzed in order to understand the reason why the residential sector is so energy intensive and define the best energy-efficiency measures (figure 4). More than the $80 \%$ of dwellings in all the areas analyzed have been built up to 1991, before the first law aiming at improving thermal performances was introduced in Italy. Another important result coming from the investigation phase is the low incidence of renewable energy production for all the areas analyzed, on average equal to $2 \%$. The result suggests the important contribute in terms of GHG emission reduction, which could come from the introduction of renewables.

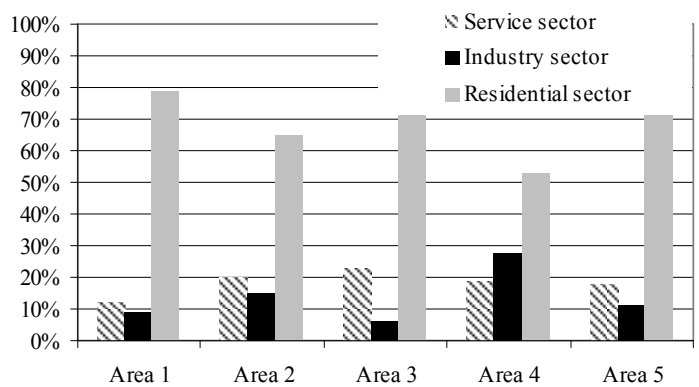

Figure 2: Thermal consumption.

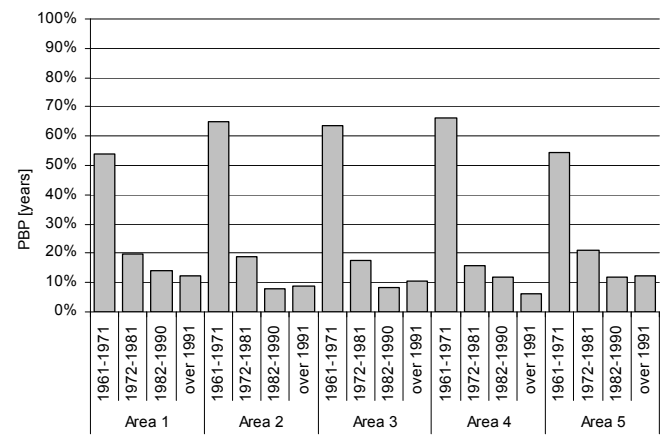

Figure 3: Number of dwellings by year of construction. 
Eventually, the public sector has been analyzed in detail with the aim of planning important energy saving initiatives to reduce the public sector energy bill and to drive energy saving actions. Graph 5 shows the electric and thermal energy consumption of schools, offices and sport facilities in the five areas. Data collected suggest several actions which can be adopted in order to maximize the energy bill reduction, such as thermal insulation in schools which most affect the municipal thermal consumption, the introduction of electric efficiency equipment in offices, which reveals to have a big impact in the electric consumption and the introduction of CHP plants in sport facilities.

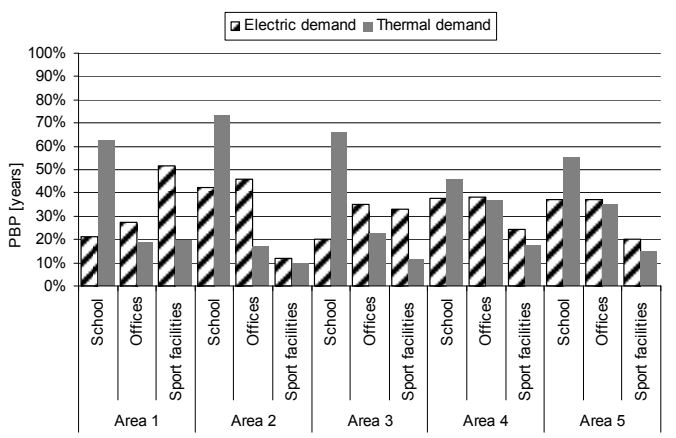

Figure 4: Energy consumption in the public sector.

\section{Analysis phase}

This paragraph deals with significant and repeatable actions studied for the main activity sectors with a focus on the energy measures for municipal sector.

\subsection{Residential sector}

Several initiatives were studied for the residential sector: (i) thermal insulation actions for dwellings built before 1991, (ii) adoption of Italian law 192/2005 in the existing municipal 'building code' aiming at reducing the primary energy building consumption, (iii) information campaign for high-energy efficiency household equipment, (iv) replacement of electric boilers with solar collector systems, (v) introduction of micro-CHP devices. As mentioned in the analysis phase the residential sector is the main responsible for thermal consumption, mainly due to a lack of accurate thermal insulation building design. Although the procedure to reduce the thermal losses implies an accurate survey of thermophysical performances of the building envelope, a standard action has been analyzed in order to assess its potential contribution to clean air policy. The standard thermal insulation action is referred to an apartment of 100 square meter area, built before 1991; the energy savings have been calculated applying the best available techniques and materials. It has been assessed a primary energy reduction of about $35 \%$, the resulting payback period, considering the revenue 
deriving from the reduction in energy bill, is of about twelve years (Table 2). The second energy saving measure analyzed addresses new buildings. The contribution coming from the adoption of Italian law Decree 192/2005 in the existing municipal 'building code' has been assessed. The Italian Legislative Decree n. 192 (and its corrections and integrations by Legislative Decree $29^{\text {th }}$ December 2006, n. 311) brought into force the Directive 2002/91/CE on energy efficiency in buildings. The Decree aims at improving buildings energy performances strengthening the thermal insulation standards. Furthermore the Italian law established additional measures such as the satisfaction of more than $50 \%$ of hot water demand by solar generation and compulsory installation of 1 $\mathrm{kWel}$ photovoltaic panels for each new dwelling. The primary energy consumption for a unit property in the five areas analyzed is, on average, 1.1 toe/year. The introduction of law 192/2005 will decrease the total energy consumption down to 0.75 toe/year, on average. Another important item in residential energy consumption is the electric equipment used in dwellings. It has been assessed the energy savings coming from the introduction of high efficiency household equipment driven by an information campaign developed by municipalities. The results are based on the data reported in literature and shown in table 3. Another interesting measure studied for the residential sector is the replacement of electric water boilers with solar collector systems. In fact, although in the areas analyzed an extensive natural gas pipeline network makes the building sector dependent on this source for space heating, tap water heating and cooking, it has been found out that a small percentage of dwellings use electric water boilers. Table 2 sums up the costs connected to the action and the relative payback period. It has been supposed to apply flat-plane solar collectors characterized by an energy-efficiency of 32\% when solar radiation is of 4.6 $\mathrm{kWh} / \mathrm{m}^{2} /$ day. Eventually it has been evaluated the introduction of microCombined Heat and Power, micro-CHP, generation in residential sector, which can be considered one of the most innovative and interesting solution due to its high potential. Micro-cogeneration technologies are expected to play an important role in greenhouse gas emission reduction, as they ensure reliable energy production and may become competitive quite soon [5].

The European Parliament has recognized cogeneration and microcogeneration as efficient technologies capable of providing energy savings and of helping achieve climate policy objectives [6]. The market for most microcogeneration technologies is still immature, largely due to technical and

Table 2: Energy and economic assessment of energy-savings measures analyzed in the residential sector.

\begin{tabular}{|c|c|c|c|}
\hline & Investment cost $(€)$ & Energy savings & PBP (years) \\
\hline thermal insulation & $25-35,000$ & $35 \%$ & 12 \\
\hline $\begin{array}{c}\text { electric boiler } \\
\text { replacement with solar } \\
\text { collector systems }\end{array}$ & $800 € / \mathrm{m}^{2}$ & 0,014 toe $/ \mathrm{m}^{2} /$ year & 4 \\
\hline micro-CHP & $12,000 €$ & $15 \%$ & 7 \\
\hline
\end{tabular}


non-technical barriers, e.g. cost of the investment, red tape, suboptimal product quality (required to gain market trust), and lack of information (essential for the spread of the technology). Moreover little research has been done on the longterm cost and benefits of the technology; for instance the investment required to adapt transmission and distribution networks to its widespread use has not been clearly addressed [7]. Several combined heat and power systems are suitable for residential sector applications [8], i.e. reciprocating internal combustion engines, micro-turbines, fuel-cells and Stirling engines, from an economic point of view internal combustion Engine perform better. A detached house was considered as a 'standard case', it was assumed to apply a $5 \mathrm{kWel} \mathrm{ICE}$; results shown in table 2 come from a previous study of the present authors [9].

Table 3: Energy savings derived from the introduction of high efficiency household equipment.

\begin{tabular}{|c|c|c|c|c|c|}
\hline & Refrigerator & $\begin{array}{c}\text { Washing } \\
\text { machine }\end{array}$ & $\begin{array}{c}\text { Dish } \\
\text { washing } \\
\text { machine }\end{array}$ & Freezer & $\begin{array}{c}\text { High } \\
\text { efficiency } \\
\text { lamps }\end{array}$ \\
\hline $\begin{array}{c}\text { energy savings } \\
\text { (toe/year) }\end{array}$ & 0.019 & 0.009 & 0.008 & 0.022 & 0.0146 \\
\hline $\begin{array}{c}\text { percentage } \\
\text { number per } \\
\text { dwelling }\end{array}$ & $110 \%$ & $37 \%$ & $100 \%$ & $25 \%$ & $435 \%$ \\
\hline $\begin{array}{c}\text { high efficiency } \\
\text { equipment } \\
\text { installed so far }\end{array}$ & $41.7 \%$ & $38.9 \%$ & $32.2 \%$ & $32.2 \%$ & $25 \%$ \\
\hline
\end{tabular}

\subsection{Service sector}

The service sector comprises buildings of private and public ownership. The private sector is characterized by different end-users in terms of energy demand, such as offices, hotels, supermarket, suitable for different energy-saving initiatives. It has been chosen to analyze two significant and repeatable measures: (i) the introduction of CHP plant in private swimming pools, which can be repeated for municipal swimming pools, (ii) the introduction of distributed generation system and polygeneration in supermarkets. Swimming pools are really suitable for the introduction of combined CHP systems due to an important need of thermal energy during the whole year. The energy demand for a swimming pool in one of the area analyzed has been taken as 'standard case' in order to assess the profitability of the investment. The hypothesis was to introduce a $100 \mathrm{kWel}$ microturbine connected in parallel to the grid. Microturbines technology represents, nowadays, a potential alternative to ICE [10], particularly in the context of mini-cogeneration, by comparison with ICE, though they have a lower electrical efficiency and a higher initial cost, they are more compact and lightweight, they require less maintenance and they have a longer working life, thanks to a more straightforward architecture. Results are shown in table 4 . Supermarkets are characterized by a strong demand for energy for refrigeration for food preservation and for ambient air-conditioning during 
the summer. This makes supermarkets particularly suitable for trigeneration applications with the prime mover coupled with absorption systems. Based on results of a study developed by the authors [11], it has been assumed to introduce trigeneration systems for the combined production of electricity and ambient heating and air-conditioning energy combining it with photovoltaic systems.

The analysis has been developed on the basis of the consumption of a typical supermarket characterized by a sales area of $10,000 \mathrm{~m}^{2}$. Results are shown in table 4. In the public sector the initiatives analyzed are: (i) street lighting energy saving measures, (ii) thermal insulation in schools and (iii) installation of photovoltaic panels, PV, in public areas. Furthermore it has been assumed to introduce CHP in municipal swimming pool as previously introduced. The street lighting energy saving measures concern (i) the replacement of high pressure sodium (HPS) lighting with LED technology for outdoor application, and (ii) the replacement of incandescent lighting with LED technology in traffic lights systems. LED technology is characterized by several benefits such as longer lifetime, less maintains, high color brightness and efficacy. Tables 5 and 6 compare, respectively the sodium high pressure technology and the incandescent lamp with LED technology.

As in the residential sector, a standard thermal insulation action has been planned for schools; the results are reported in table 7 . It has assessed a $30 \%$ reduction of primary energy consumption. The last initiative analyzed is the introduction of PV panels in public area. Solar energy is a strategic source for the areas analyzed. The problem connected with the introduction of PV energy in the

Table 4: Energy and economic assessment of energy-savings measures analyzed in the service sector.

\begin{tabular}{|c|c|c|c|}
\hline & $\begin{array}{c}\text { Investment cost } \\
(€)\end{array}$ & $\begin{array}{c}\text { Energy } \\
\text { savings }\end{array}$ & $\begin{array}{c}\text { PBP } \\
\text { (years) }\end{array}$ \\
\hline CHP in swimming pools & 160,000 & 60 toe/year & 7 \\
\hline DG \& polygeneration in supermarkets & $3,500,000$ & $40 \%$ & 9 \\
\hline
\end{tabular}

Table 5: Comparison between HPS and LED technology.

\begin{tabular}{|c|c|c|c|}
\hline & & HPS & LED \\
\hline lamp power & (W) & 150 & 40 \\
\hline lifetime & (hours) & 10,000 & 100,000 \\
\hline operational hours & (hours/year) & \multicolumn{2}{|c|}{3,500} \\
\hline energy saving for each replacement & (toe/year) & \multicolumn{2}{|c|}{0.07} \\
\hline
\end{tabular}

Table 6: Comparison between incandescent lamp and LED technology.

\begin{tabular}{|c|c|c|c|}
\hline & & HPS & LED \\
\hline lamp power & (W) & 70 & 13 \\
\hline lifetime & (hours) & 5,000 & 100,000 \\
\hline operational hours & (hours/year) & \multicolumn{2}{|c|}{2,900} \\
\hline energy saving for each replacement & (toe/year) & \multicolumn{2}{|c|}{0.03} \\
\hline
\end{tabular}


public sector is the high investment required to the municipality. A possible solution is to let public areas to a private company which recognizes a fee to the municipal administration for a negotiated number of years. Another possible solution is an agreement with an Energy Service Company, ESCo; in this case the municipal institution can keep its energy costs constant and the ESCo retains ownership over the equipment until the end of the contract. During the contract duration the municipality is paying the same energy costs, but in the form of a service fee to the ESCo, in this service fee also included equipment modernization which is provided by the ESCo [12].

This is an opportunity to modernize the municipal equipment. Table 7 shows the parameters considered in the evaluation of the energy savings related to the $\mathrm{PV}$ initiative.

\subsection{Industry sector}

The introduction of distributed generation, DG, systems has been studied in order to make the industry sector as self-sufficient as possible. Using DG systems [13] offers a number of advantages, such as a reduction in the energy costs for the users and for the domestic and international economies as a whole, fewer losses in transmission, fewer carbon dioxide emissions, a better quality electrical energy generation and a less vulnerable electrical system. CHP plants have been assessed in the condition of contemporary demand of electric and thermal energy. It has been analyzed the possibility to feed the CHP plants with natural gas or biomass, particularly interesting for small plant (1-2 $\left.\mathrm{MW}_{\mathrm{el}}\right)$. Biomass is a renewable energy and it proves an interesting GHG emission reduction in case of 'short-chain' biomass plants. It means that the maximum distance between biomass production and usage must be within 50 kilometers.

Table 8 shows CHP investment cost per $\mathrm{kW}$ of electric energy installed; the energy savings and the relative $\mathrm{PBP}$ has been reported with reference to a 'typical' case. In case of biomass fuel it can be seen a reduction in the payback period derived from the national incentive of green certificate mechanism, which is a market mechanism introduced in Italy for incentivizing power generation from renewable sources.

Table 7: Energy and economic assessment of energy-saving measures in the public sector.

\begin{tabular}{|c|c|c|c|}
\hline & $\begin{array}{c}\text { Investment cost } \\
(€)\end{array}$ & $\begin{array}{c}\text { Energy } \\
\text { savings }\end{array}$ & $\begin{array}{c}\text { PBP } \\
\text { (years) }\end{array}$ \\
\hline thermal insulation in schools & 50,000 & $33 \%$ & 12 \\
\hline PV panel in public area & $/$ & 0.187 toe $/ \mathrm{kWh}$ & 10 \\
\hline
\end{tabular}

Table 8: $\quad$ Energy-economic assessment of CHP in the industry sector.

\begin{tabular}{|c|c|c|c|}
\hline & $\begin{array}{c}\text { Investment cost } \\
(€ / \mathrm{kW})\end{array}$ & $\begin{array}{c}\text { Energy savings } \\
\text { (toe/year) }\end{array}$ & $\begin{array}{c}\text { PBP } \\
\text { (years) }\end{array}$ \\
\hline natural gas feeding & $1,200 €$ & 9,000 & 7 \\
\hline biomass feeding & $2,000 €$ & 13,000 & 5 \\
\hline
\end{tabular}




\section{Executive phase}

The potential primary energy reduction, derived from the energy saving actions analyzed, has been assessed and it has been evaluated its real feasibility on the basis of factors deduced from literature and author's experience (Table 9). A 5 year time period has been considered to take up all the initiatives developed. The results show the annual savings and emission reduction achievable since 2015. The GHG emission reduction has been calculated using an emission factor of 3 ton $\mathrm{CO}_{2}$ /toe, on the basis of the actual savings previously assessed. As far as the service sector is concerned it has been assumed that, at least, a CHP plant will be installed in a supermarket and in a private or municipal swimming pool by 2015 . The results emphasize the important contribution in GHG emission reduction coming from municipal energy policy, a big contribution deriving from industry residential sector. As far as the service sector is concerned, more than half contribution come from the public sector, which, furthermore, can drive changes in the other sectors, especially in dwellings, through good practices.

Eventually, some generalized factors (table 10) have been found out in order to assess the municipal policy coming from the residential sector, an important aspect comes from the fact that each datum refers to one average dwelling.

Table 9: Emission reduction derived from the implementation of the energy savings initiatives.

\begin{tabular}{|c|c|c|c|c|}
\hline & $\begin{array}{l}\text { Potential } \\
\text { savings } \\
\text { (toe/year) }\end{array}$ & $\begin{array}{l}\text { Factor } \\
(\%)\end{array}$ & $\begin{array}{c}\text { Actual } \\
\text { savings } \\
\text { (toe/year) }\end{array}$ & $\begin{array}{l}\text { GHG reduction } \\
\text { (tonnCO } \mathrm{CO}_{2} / \text { year) }\end{array}$ \\
\hline \multicolumn{5}{|c|}{ Residential sector } \\
\hline Thermal insulation & 73,689 & $30 \%$ & 22,107 & 66,320 \\
\hline Electric boiler replacement & 4,456 & $40 \%$ & 1,782 & 5,347 \\
\hline High efficiency lamp & 6,044 & $50 \%$ & 3,022 & 9,066 \\
\hline $\begin{array}{l}\text { High efficiency household } \\
\text { equipment }\end{array}$ & 3,279 & $65 \%$ & 2,131 & 6,393 \\
\hline Building code & & 1 & 540 & 1,620 \\
\hline Micro-CHP & 23,487 & $5 \%$ & 1,174 & 3,523 \\
\hline \multicolumn{5}{|c|}{ Service sector } \\
\hline CHP in swimming pool & 1 & / & 755 & 2,265 \\
\hline DG in supermarket & / & / & 3,000 & 9,000 \\
\hline Public lighting measures & 1 & 1 & 1,799 & 5,397 \\
\hline Thermal insulation in schools & 1 & 1 & 1,787 & 5,361 \\
\hline PV panel in public areas & l & 1 & 1,665 & 4,995 \\
\hline \multicolumn{5}{|c|}{ Industry sector } \\
\hline DG system & & & 35,000 & 105,000 \\
\hline Total & & & 74,763 & 224,288 \\
\hline
\end{tabular}




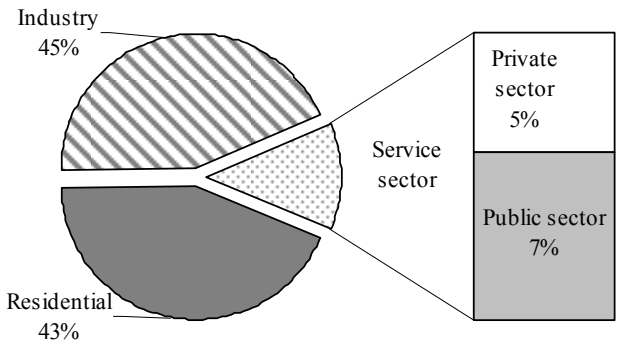

Figure 5: GHG emission reduction share in the five urban areas analyzed.

Table 10: Generalized factors suitable to assess the GHG emission reduction contribution derived from municipal energy planning.

\begin{tabular}{|c|c|c|}
\hline & toe/apartment & tonnCO $\mathrm{CO}_{2} /$ apartment \\
\hline thermal insulation & 0.16 & 0.48 \\
\hline $\begin{array}{c}\text { electric boiler replacement with solar collector } \\
\text { systems }\end{array}$ & 0.013 & 0.039 \\
\hline high efficiency lamp & 0.023 & 0.069 \\
\hline high efficiency household equipment & 0.016 & 0.048 \\
\hline efficiency building criteria in 'building code' & 0.004 & 0.012 \\
\hline micro-CHP & 0.009 & 0.027 \\
\hline
\end{tabular}

\section{Conclusion}

The present paper analyzes and assesses from technical, economic and environmental viewpoints different initiatives in energy sector aiming at increasing energy efficiency in end use and reducing overall carbon emissions. Results are based on local energy planning studies for five Italian urban areas with about fifty thousand inhabitants. The analysis has been developed in order to reach generally applicable criteria suitable to evaluate the local energy policy contribute to the greenhouse gas (GHG) emissions reduction. The results point out the important contribution in GHG emission reduction coming from municipal institution, and the important role played by the municipalities in driving energy saving initiatives.

\section{Acknowledgements}

The authors are gratefully indebted to the five municipalities, in the Marche Region of Italy, which were the object of the analysis: Pesaro, Fano, Senigallia, Ascoli Piceno, San Benedetto. 


\section{References}

[1] Copenhagen Accord, 18 December 2009, United Nations Framework Convention on Climate Change. Online. http://unfecc.int/resource/ docs/2009/cop15/eng/107.pdf

[2] R.B. Hiremath, S. Shikha, N.H. Ravindranath, Decentralized energy planning; modeling and application-a review, Renewable and Sustainable Energy Reviews, 11(5), pp. 729-752, 2005

[3] J. Byrnea, K. Hughesa, W. Rickersona, L. Kurdgelashvilia, American policy conflict in the greenhouse: Divergent trends in federal, regional, state, and local green energy and climate change policy, Energy Policy, 35(9), pp. 4555-4573, 2007.

[4] J. Stenlund Nilsson, A. Martensson, Municipal energy-planning and development of local energy-systems, Applied Energy, 76(1-3), pp.179187, 2003.

[5] A.D. Hawkes, M.A. LeachCost-effective operating strategy for residential micro-combined heat and power, Energy, 32(5), pp. 711-732, 2007.

[6] H.I. Onovwiona, V.I. Ugursal, Residential cogeneration systems: review of the current technology, Renewable and Sustainable Energy Reviews, 10(5), pp. 389-431, 2006.

[7] M. De Paepe, P. D'Herdt, D. Mertens, Micro-CHP systems for residential applications, Energy Conversion and Management, 47(18-19), pp. 34353446, 2006.

[8] V. Kuhn, J. Klemeš, I. Bulatov, MicroCHP: Overview of selected technologies, products and field test results, Applied Thermal Engineering, 28(16), pp. 2039-2048, 2008.

[9] A. Arteconi, C. M. Bartolini, C. Brandoni, Energy and economic analysis of small-scale distributed generation in the residential sector, Proc. of the 14 ${ }^{\text {th }}$ Int. Conf. On Stirling Engine, 2009.

[10] J. Kaikko, J. Backman, Technical and economic performance analysis for a microturbine in combined heat and power generation, Energy, 32(4), pp. 378-387, 2007.

[11] A. Arteconi, C. Brandoni, F. Polonara, Distributed generation and trigeneration: Energy saving opportunities in Italian supermarket sector, Applied Thermal Engineering, 29(8-9), pp. 1735-1743, 2009.

[12] S. Rezessya, K. Dimitrov, D. Urge-Vorsatz, S. Baruch, Municipalities and energy efficiency in countries in transition: Review of factors that determine municipal involvement in the markets for energy services and energy efficient equipment, or how to augment the role of municipalities as market players, Energy Policy, 34(2), pp. 223-237, 2006.

[13] G. Chicco, P. Mancarella, Distributed multi-generation: A comprehensive view, Renewable and Sustainable Energy Reviews, 13(3), pp. 535-551, 2009. 